\section{Analysis of DNA Methylation Sites used for Forensic Age Prediction and their Correlation with Human Aging}

\author{
Silva DSBS ${ }^{1 *}$ and Karantenislis $\mathbf{G}^{2}$ \\ ${ }^{1}$ Department of Chemistry, Hofstra University, Hempstead-NY, USA \\ ${ }^{2}$ John F Kennedy High School, Bellmore-NY, USA
}

\begin{abstract}
Phenotype-related features, such as age, are linked to genetic components through regulatory pathways and epigenetic modifications, such as DNA methylation, are major regulators in the translation of genotype to phenotype. Age-related CpG sites have been identified and described to have predictive value in the estimation of chronological age from biological samples. Currently, CpG sites are chosen based only on statistical correlation with age, and not based on their location on the chromosome or on the function of genes where they are located. There seems to be a lack of information regarding the identified genes and if they have a direct or indirect relation to the aging process, or if the statistical correlation is more likely to be random. In this work, we analyzed studies published in the last six years on DNA methylation age markers and a total of 59 genes were identified as being age-related. The five most used ones by different prediction models were: ELOVL2, FHL2, KLF14, TRIM59 and C1orf132. After further investigation, it was possible to notice that although the function of genes is not the primary criteria when choosing targets to build age prediction models, it is clear that the statistical correlation found between DNA methylation and age is not random. The sites and genes chosen by different studies have mostly direct association with aging, playing important roles in metabolism, cell proliferation, migration and immune signaling pathways, and also being involved in inflammatory responses and in cancer development.
\end{abstract}

Keywords: Age prediction; DNA methylation; Forensic epigenetics; Investigative lead

*Corresponding author: Silva DSBS, Department of Chemistry, Hofstra University, Hempstead-NY, USA, Tel: +1 516.463.7153; E-mail: Deborah.silva@hofstra. edu

Citation: Silva DSBS, Karantenislis G (2021) Analysis of DNA Methylation Sites used for Forensic Age Prediction and their Correlation with Human Aging. Forensic Leg InvestigSci 7: 054.

Received: March 19, 2021; Accepted: April 02, 2021; Published: April 09, 2021

Copyright: (C) 2021 Silva DSBS, et al. This is an open-access article distributed under the terms of the Creative Commons Attribution License, which permits unrestricted use, distribution, and reproduction in any medium, provided the original author and source are credited.

\section{Introduction}

DNA samples left behind in crime scenes are often used for identification purposes by comparing them to reference samples or to a forensic database. In cases where there is no match, investigators may turn to alternative approaches using advanced technologies to gain valuable leads on phenotypic traits (externally visible characteristics) of the person who had left the DNA material. Previous studies have found that phenotypes can be predicted by using information obtained from different DNA markers, such as single nucleotide polymorphisms (SNPs), insertion/deletion polymorphisms (InDel), and epigenetic markers [1-11]. It is well established that epigenetic modifications are major regulators in the translation of genotype to phenotype. Epigenetic regulation encompasses various levels of gene expression and involves modifications of DNA, histones, RNA and chromatin, with functional consequences for the human genome [12-14]. DNA methylation is the most well-characterized epigenetic modification. It is usually associated with transcriptional repression and it involves the addition of a methyl group (- CH3) in the cytosine of $\mathrm{CpG}$ dinucleotides. Differences in DNA methylation levels in specific regions of the genome can affect the expression of target genes and downstream phenotypes. As differential methylation patterns began being more widely described, research started focusing on understanding how variations in human DNA methylation patterns can be used to describe and predict phenotype-related features, such as age. Age-related $\mathrm{CpG}$ sites have been identified and have been described to have predictive value in the estimation of chronological age from biological samples [15-18].

The most current used methodology to identify $\mathrm{CpG}$ sites consists in using data obtained from DNA methylation arrays, such as the Infinium HumanMethylation450 Bead Chip array (Illumina, CA). This platform interrogates over 450,000 individual $\mathrm{CpG}$ sites and quantifies DNA methylation by measuring signal intensity emitted by methylated and un methylated probes. Then, the analysis software will use these probe intensities to calculate beta-values, which will provide an estimated methylation status. For example, a $\mathrm{CpG}$ site with a 0.9 beta-value is estimated to have $90 \%$ methylation [18]. Most age prediction studies use methylation raw data from different tissue samples followed by the extraction of beta-values for each $\mathrm{CpG}$ site. Then, CpG sites highly correlated to age are selected and a statistical model for age prediction is developed [19]. Based on this description of the selection of $\mathrm{CpG}$ sites, it is clear that they are not primarily chosen based on their location on the chromosome or on the function of the genes where they are located. Rather, $\mathrm{CpG}$ sites are chosen based only on statistical correlation with age. Published studies on age prediction usually present the sites chosen and briefly mention the genes involved. There seems to be a lack of information regarding the identified genes and if they have a direct or indirect relation to the aging process, or if the statistical correlation is more likely to be random. Hence, this study aimed to evaluate the current progress in forensic age prediction based on DNA methylation patterns and to investigate the identified sites/genes and their significance and correlation with human aging. 
Citation: Silva DSBS, Karantenislis G (2021) Analysis of DNA Methylation Sites used for Forensic Age Prediction and their Correlation with Human Aging. Forensic Leg InvestigSci 7: 054.

\section{Materials and Methods}

A comprehensive review of articles on forensic age prediction was done to identify previously published age-related DNA methylation markers and to gather information on $\mathrm{CpG}$ sites, gene, age estimation error and sample type. The most commonly used $\mathrm{CpG}$ sites in different age prediction models were identified and an investigation of the genes where these markers are located was performed. The identified genes and their correlation with any aging process were evaluated by using information found on the National Center for Biotechnology Information (NCBI) [20] and the Gene Cards [21] databases.

\section{Results and Discussion}

Despite all work done so far in investigating DNA methylation markers for age prediction, some aspects of age estimation based on epigenetic data need to be further understood. As seen in the studies published to date, there seems to be a functional link between DNA methylation and age since the regulatory regions of some genes have a tendency to become more methylated with the increase of age [22]. However, while studies report $\mathrm{CpG}$ sites identified as presenting a relation to human aging, there is a lack of further information on the genes where these $\mathrm{CpG}$ sites are located and if these sites are direct or indirectly associated to the aging process.

A total of 29 studies on DNA methylation age markers published in the last six years were analyzed to evaluate the current progress in forensic age prediction and to better investigate the sites and genes identified by different authors. The results from this investigation are presented in (Table 1). Most of the age predictions models were built on results gathered from blood sample analysis. However, an ideal age prediction tool should work for different body fluids, and for this reason, more recent studies have been focusing on expanding the tissue-type analyzed to at least include the most common types of body fluids found in crime scenes, such as saliva and semen [23-47].

\begin{tabular}{|c|c|c|c|}
\hline Study & Genes & $\begin{array}{l}\text { Mean absolute deviation or predic- } \\
\text { tion error }\end{array}$ & Sample type \\
\hline Weidner et al. [23] & ITGA2B, ASPA, PDE4C & 4.5 years & blood \\
\hline Yi et al. [15] & $\begin{array}{l}\text { TBOX3, GPR137, ZIC4, ZDHHC22, MEIS1, UBE2E1, PTDSS2, } \\
\text { UBQLN1 }\end{array}$ & NA & blood \\
\hline Zbiec-Piekarska et al. [17] & ELOVL2, C1orf132, TRIM59, KLF14, FHL2 & 3.9 years & blood \\
\hline Lee et al. [24] & TTC7B, NOX4 & 5.4 years & semen \\
\hline Bekaert et al. [25] & ASPA, PDE4C, ELOVL2, EDARADD & $\begin{array}{l}3.8 \text { years (blood) and } 4.9 \text { years } \\
\text { (teeth) }\end{array}$ & blood, teeth \\
\hline Xu et al. [26] & ADAR, ITGA2B, PDE4C & 5.1 years & blood \\
\hline Huang et al. [27] & ASPA, ITGA2B, NPTX2 & 7.9 years & blood \\
\hline Park et al [18] & ELOVL2, ZNF423, CCDC102B & 3.4 years & blood \\
\hline Friere-Aradas et al [28] & ELOVL2, ASPA, PDE4C, FHL2, CCDC102B, C1 orf132 & 3.1 years & blood \\
\hline Zubakov et al. [30] & DMH1, DMH2, DMH3, FHL2, ELOVL2 & 4.3 years & blood \\
\hline Hong et al [31] & SST, CNGA3, KLF14, TSSK6, TBR1, SLC12A5, PTPN7 & 3.2 years & saliva \\
\hline Alghanim et al. [32] & KLF14, SCGN & $\begin{array}{l}7.1 \text { years (saliva) and } 10.3 \text { years } \\
\text { (blood) }\end{array}$ & blood, saliva \\
\hline Cho et al. [33] & ELOVL2, C1orf132, TRIM59, KLF14, FHL2 & 3.3 years & blood \\
\hline Naue et al. [34] & ELOVL2, F5, KLF14, TRIM59 & 3.6 years & blood \\
\hline Vidaki et al. [35] & NHLRC1, SCGN, CSNK1D & $\begin{array}{l}7.1 \text { years (blood) and } 3.2 \text { years } \\
\text { (saliva) }\end{array}$ & blood, saliva \\
\hline Li et al. [36] & NHLRC1, SCGN, ASPA, EDARADD, CSNK1D, LAG3 & $\begin{array}{l}4.1 \text { years (healthy samples) and } 7.1 \\
\text { years (diseased samples) }\end{array}$ & blood \\
\hline Alifieri et al. [37] & $\begin{array}{l}\text { VGF, TRIP10, KLF14, CSNK1D, FZD9, C21orf63, SSRP1, NHLRC1, } \\
\text { ERG, FXN, P2RXL1, SCGN }\end{array}$ & $\begin{array}{l}4.1 \text { years (blood) and } 7.3 \text { years } \\
\text { (saliva) }\end{array}$ & blood, saliva \\
\hline Feng et al. [38] & TRIM59, PDE4C, ELOVL2, CCDC102B, C1orf132, RASSF5 & 2.8 years & blood \\
\hline Gentile et al. [41] & ELOVL2, C1orf132, TRIM59, KLF14, FHL2 & $\begin{array}{l}5.4 \text { years (highest MAD by age } \\
\text { group) }\end{array}$ & saliva \\
\hline $\mathrm{Xu}$ et al. [42] & $\begin{array}{l}\text { SALL4, MBP, C17orf76, B3GALT6, NOC2L, SNN, NPTX2, } \\
\text { SLC22A18, TMEM106A, LEP, SCAP, C16orf30, FLJ25410 }\end{array}$ & 4.7 years & $\begin{array}{l}\text { bonemarrow, dermal fibroblast, buccal, } \\
\text { prostate NL, sperm, saliva, colon, breast } \\
\text { NL, muscle, placenta, liver, fat adip, brain } \\
\text { occipital cortex, brain CRBLM }\end{array}$ \\
\hline Dias et al. [43] & ELOVL2, FHL2, EDARADD, PDE4C, C1orf132 & 8.8 years & blood \\
\hline Heidegger et al. [44] & ELOVL2, FHL2, KLF14, MIR29B2CHG, TRIM59 & NA & blood \\
\hline
\end{tabular}


Citation: Silva DSBS, Karantenislis G (2021) Analysis of DNA Methylation Sites used for Forensic Age Prediction and their Correlation with Human Aging. Forensic Leg InvestigSci 7: 054.

\begin{tabular}{|c|c|c|c|}
\hline Lee et al. [45] & TMEM51, TRIM59, ELOVL2, and EPHA6 & NA & bones \\
\hline Li et al. [46] & NOX4 & $\begin{array}{c}4.2 \text { years (liquid semen and fresh } \\
\text { seminal stains), } 4.4 \text { years (aged semi- } \\
\text { nal stains), 3.9 years (mixed stains) }\end{array}$ & $\begin{array}{c}\text { sperm } \\
4.6 \text { years }\end{array}$ \\
\hline Pan et al. [47] & ASPA, EDARADD, CCDC102B, ZNF423, ITGA2B, KLF14, FHL2 & 7.1 years \\
\hline Sukawutthiya et al. [22] & ELOVL2 & blood \\
\hline
\end{tabular}

Table 1: Information on DNA methylation-based age prediction studies.

NA $=$ not available

MAD values are shown for the validation/training sets

A total of 59 genes were identified as being age-related and the five most used ones were ELOVL2, FHL2, KLF14, TRIM59 and Clorf132. All genes are protein coding genes, except for Clorf132, which is a ncRNA gene type. Interestingly, most of the identified genes ( 44 of the 59) were not used by multiple studies, being part of only one age prediction model. More information on the less cited genes can also be found in Supplementary Table 1.

CpG sites in the ELOVL2 gene were the most used ones by multiple studies (Supplementary Table 1). The ELOVL2 gene also seems to be part of the predictive models with the lowest absolute deviation.ELOVL2 (elongation of very-long-chain fatty acids-like 2) plays a role in metabolism, including omega- 3 and omega- 6 metabolism, and it is also related to transferase and fatty acid elongase activities [48]. Chen et al [49] investigated the ELOVL2 association to functional and anatomical aging in vivo, focusing on mouse retina. ELOVL2 is involved with the elongation of long-chain omega-3 and omega- 6 polyunsaturated acids, which play essential roles in retinal function. The authors reported that the ELOVL2 promoter region is increasingly methylated with age in the retina and that the decrease in the expression of this gene can be a regulator of a molecular aging clock in the retina. Also, according to Bacalini et al. [50], ELOVL2 methylation is related to cell replication and the target regions within ELOVL2 get hypermethylated with cell divisions. Based on other studies [51], the authors suggest that ageing is affected by the number of cell divisions and that the extend life span is related to a decrease in division rate. Also, the same authors present the idea that since ELOVL2 hypermethylation occurs in different tissues; this locus is a target of methyltransferase activity throughout cell replications. The second locus most used by different studies was the FHL2 (Four and a Half LIM Domains Protein 2) gene which encodes a protein that plays a role in the assembly of extracellular membranes [52]. This gene is also related to transcription activity, cell proliferation, apoptosis, adhesion, migration, structural stability, and tissue repair and inflammation [53]. According to Cao et al [54], FHL2 plays an important role in cancer cell invasion, migration and adhesion to extracellular matrix, and the mutations in this gene and posttranslational modifications may also contribute to carcinogenesis.

The KLF14 (Kruppel Like Factor 14) gene was used in age prediction models proposed by ten different studies. This gene encodes a protein that functions as a transcriptional co-repressor [55]. Genome-wide association studies (GWAS) have also shown that KLF14 play an important role in the development of metabolic diseases and that variants near this gene are associated with T2DM (type 2 diabetes mellitus) and HDL-C (high-density lipoprotein cholesterol) [56]. Assuncao et al [57] showed that besides being a regulator of lipid metabolism, KLF14 also mediates lipid signaling. And to further support these findings, [56] showed that the inhibition of glucose uptake induced by high glucose and high insulin can be prevented by the over expression of $K L F 14$. More recently, it has been shown that KLF14 is involved in chronic inflammatory responses and in atherosclerosis development $[58,59]$. The fourth most used gene by the studies analyzed in this work was TRIM59 (Tripartite Motif Containing 59), a protein coding gene that is involved in the innate immune signaling pathways [60]. TRIM59 was also shown to be involved in the induction of cellular senescence by affecting Ras and RB signal pathways [61] and to be a promoter of growth and migration in different types of cancer $[59,62]$.

Clorf132 (Chromosome 1 Open Reading Frame 132), currently known as MIR29B2CHG (MIR29B2 And MIR29C Host Gene) is the fifth most cited gene. This is an RNA gene part of the lncRNA class and a mir-29 microRNA precursor [63]. microRNAs regulate the translation of proteins and the mir-29 family members were shown to be down-regulated in different types of cancers [64].

As presented in this section and in the supplemental material (Supplementary Table 1), the sites and genes chosen by different studies and that contribute to age prediction have mostly direct association with aging, playing important roles in metabolism, cell proliferation, migration and immune signaling pathways, and also being involved in inflammatory responses and in cancer development.

During life, humans are exposed to many environmental factors that affect the level of methylation in different genes. Most likely, some locations in the chromosomes are more sensitive to changes in the environment and for this reason they present a stronger correlation to the ageing process and provide better markers to be used in predictive models [59]. It is also interesting to point out that in order to create more accurate and reliable age prediction models in forensic practice, researchers should also focus on exploring RNA genes, such as MIR29B2CHG. This type of gene has shown to have direct and indirect effects of DNA methylation and protein expression and can add value to prediction models when combined with other strongly age-associated genes, such as ELOVL2.

Although the function of genes is not the primary criteria when choosing targets to build age prediction models, it is clear that the statistical correlation between DNA methylation and age obtained from the analysis of methylation arrays is not random. The information presented in this work shows how important it is to investigate and discuss the function of the genes and sites used in the prediction models. Future publications should include function information on the targeted genes to provide an extra layer of information to forensic investigators while using this type of investigative tool.

\section{Acknowledgement}

Georgia Karantenislis is conducting an independent graduatelevel research project as part of the Advanced Science Research (ASR) program. 
Citation: Silva DSBS, Karantenislis G (2021) Analysis of DNA Methylation Sites used for Forensic Age Prediction and their Correlation with Human Aging. Forensic Leg InvestigSci 7: 054.

\section{Declaration of Interest}

None.

\section{References}

1. Chaitanya L, Breslin K, Zuniga S, Wirker L, Pospiech E, et al. (2018) The HIrisPlex-S system for eye, hair and skin colour prediction from DNA: introduction and forensic developmental validation. Forensic Sci Int Genet 35: $123-135$.

2. Sulem P, Gudbjartsson DF, Stacey SN, Helgason A, Rafnar T, et al. (2007) Genetic determinants of hair, eye and skin pigmentation in Europeans. Nat Genet 39: 1443-1452.

3. Maronas O, Phillips C, Sochtig J, Gomez-Tato A, Cruz R, et al. (2014) Development of a forensic skin colour predictive test. Forensic Sci Int Genet 13: $34-44$.

4. Fracasso NCA, Andrade ES, Vieira CEV, Andrade CCF, Zanao LR, et al (2017) Haplotypes from the SLC45A2 gene are associated with the presence of Freckles and eye, hair and skin pigmentation in Brazil. Leg Med 25: 43-51.

5. Wood AR, Esko T, Yang J, Vedantam S, Pers TH, et al. (2014) Defining the role of common variation in the genomic and biological architecture of adult human height. Nat Genet 46: 1173-1186.

6. Weedon MN, Lango H, Lindgren CM, Wallace C, Evans DM, et al. (2008) Genome-wide association analysis identifies 20 loci that influence adult height. Nat Genet 40: 575-583.

7. Liu F, Lijn FVD, Schurmann C, Zhu GU, Chakravarty M, et al. (2012) A genome-wide association study identifies five loci influencing facial morphology in Europeans. PLoS Genet 8: e1002932.

8. Paternoster L, Zhurov AI, Toma AM, Kemp JP, Pourcain BST, et al. (2012) Genome-wide association study of three-dimensional facial morphology identifies a variant in PAX3 associated with nasion position. Am J Hum Genet 90: 478-485.

9. Nyholt DR, Na G, Heath AC, Martin NG (2003) Genetic basis of male pattern baldness. J Invest Dermatol 121: 1561-1564.

10. Kayser M (2015) Forensic DNA phenotyping: predicting human appearance from crime scene material for investigative purposes. Forensic Sci Int Genet 18: 33-48.

11. Vidaki A, Kayser M (2018) Recent progress, methods and perspectives in forensic epigenetics. Forensic Sci Int Genet 37: 180-195.

12. Fraga MF, Ballestar E, Paz MF, Ropero S, Setien F, et al. (2005) Epigenetic differences arise during the lifetime of monozygotic twins. Proc Natl Acad Sci 102: 10604-10609.

13. Haggarty $P(2015)$ Genetic and metabolic determinants of human epigenetic variation. Curr Opin Clin Nutr Metab Care 18: 334-338.

14. Lardenoije R, Iatrou A, Kenis G, Kompotis K, Steinbusch HWM, et al (2015) The epigenetics of aging and neurodegeneration. Prog Neurobiol 131: 21-64.

15. Yi SH, Xu LC, Mei K, Yang RZ, Huang DX, et al. (2014) Isolation and identification of age-related DNA methylation markers for forensic age-prediction. Forensic Sci Int Genet 11: 117-125.

16. Silva DSBSS, Antunes J, Balamurugan K, Duncan G, Alho CS, et al. (2015) Evaluation of DNA methylation markers and their potential to predict human aging. Electrophoresis 36: 1775-1780.

17. Zbiec Piekarska R, Spolnicka M, Kupiec T, Makowska Z, Spas A, et al. (2015) Examination of DNA methylation status of the ELOVL2 marker may be useful for human age prediction in forensic science. Forensic Sci Int Genet 14: 161-167.
18. Park JL, Kim JH, Seo E, Bae DH, Kim SY, et al. (2016) Identification and evaluation of age-correlated DNA methylation markers for forensic use. Forensic Sci Int Genet 23: 64-70.

19. Goel N, Karir P, Garg VK (2017) Role of DNA methylation in human age prediction. Mech Ageing Dev 166: 33-41.

20. National Center for Biotechnology Information. Accessed in November (2020).

21. Gene Cards, The Human Gene Database. Accessed in November 2020.

22. Sukawutthiya P, Sathirapatya T, Vongpaisarnsin K (2021) A minimal number CpGs of ELOVL2 gene for a chronological age estimation using pyrosequencing. Forensic Sci Int 318: 110631.

23. Weidner CI, Lin Q, Koch CM, Eisele L, Beier F, et al. (2014) Aging of blood can be tracked by DNA methylation changes at just three $\mathrm{CpG}$ sites. Genome Biol 15: R24.

24. Lee YH, Jung SE, Oh YU, Choi A, Yang WI, et al. (2015) Epigenetic age signatures in the forensicallyrelevant body fluid of semen: a preliminary study. Forensic Sci Int Genet 19: 28-34.

25. Bekaert B, Kamalandua A, Zapico SC, Voorde W, Decorte R, et al. (2015) Improved age determination of blood and teeth samples using a selected set of DNA methylation markers. Epigenetics 10: 922-930.

26. Cheng Xu, Hongzhu Qu, Wang G, Xie B, Shi Yi, et al. (2015) A novel strategy for forensic age prediction by DNA methylation and support vector regression model. Sci rep 5: 17788.

27. Huang Y, Yan J, Hou J, Fu X, Li L, et al. (2015) Developing a DNA methylation assay for human age prediction in blood and bloodstain. Forensic Sci Int Genet 17: 129-136.

28. Freire Aradas A, Phillips C, Mosquera A, Santamaria LG (2016) Development of a methylation marker set for forensic age estimation using analysis of public methylation data and the Agena Bioscience EpiTYPER system. Forensic Sci Int Genet 24: 65-74.

29. Giuliani C, Cilli E, Bacalini MG, Pirazzini C, Sazzini M, et al. (2016) Inferringchronological age from DNA methylation patterns ofhuman teeth. Am J Phys Anthropol 159: 585-595.

30. Zubakov D, Liu F, Kokmeijer I, Choi Y, Meurs JBJ, et al. (2016) Human age estimation from blood using mRNA, DNA methylation, DNA rearrangement, and telomere length. Forensic Sci Int Genet 24: 33-43.

31. Hong SR, Jung SE, lee EH, Shin KH, Yang WI, et al. (2017) DNA methylation-based age prediction from saliva: High age predictability by combination of $7 \mathrm{CpG}$ markers.Forensic SciInt Genet 29: 118-125.

32. Alghanim H, Antunes J, Silva DSBS, Alho CSBS, Balamurugan K, et al. (2017) Detection and evaluation of DNA methylation markers found at SCGN and KLF14 loci to estimate human age. Forensic SciInt Genet 31: 81-88.

33. Cho S, Junf S-E, Hong SR, Lee EH, Lee JH, et al. (2017) Independent validation of DNA-based approaches for age prediction in blood. Forensic SciInt Genet 29: 250-256.

34. Naue J, Sanger T, Hoefsloot HCJ, Lutz-Bonengel S, Kloosterman AD, et al. (2018) Proof of concept study of age-dependent DNA methylation markers across different tissues by massive parallel sequencing. Forensic SciInt Genet 36: 152-159.

35. Vidaki A, Ballard D, Aliferi A, Miller TH, Barron LP, et al. (2017) DNA methylation-based forensic age prediction using artificial neural networks and next generation sequencing. Forensic SciInt Genet 28: 225-236.

36. Li X, Li W, Xu Y (2018) Human Age Prediction Based on DNAMethylation Using a Gradient Boosting Regressor. Genes 9: 424.

37. Aliferi A, Ballard B, Gallidabino MD, Thurtle H, Barron L, et al. (2018) DNA methylation-based age prediction using massively parallel sequencing data and multiple machine learning models. Forensic SciInt Genet 37: 215-226. 
Citation: Silva DSBS, Karantenislis G (2021) Analysis of DNA Methylation Sites used for Forensic Age Prediction and their Correlation with Human Aging. Forensic Leg InvestigSci 7: 054.

38. Feng L, Peng F, Li S, Jiang Li, Sun H, et al. (2018) Systematic feature selection improves accuracy of methylation-based forensic age estimation in Han Chinese males. Forensic SciInt Genet 35: 38-45.

39. Jung SE, Lim SM, Hong SR, Lee EH, Shin KJ, et al. (2019) DNA methylation of the ELOVL2, FHL2, KLF14, C1orf132/MIR29B2C, and TRIM59 genes for age prediction from blood, saliva, and buccal swab samples. Forensic Scilnt Genet 38: 1-8.

40. Alsaleh H, Haddrill PR (2019) Identifying blood-specific age-related DNA methylation markers on the Illumina MethylationEPIC $®$ BeadChip. Forensic SciInt 303: 109944

41. Gentile F, Castoldi E, Serventi P, Colloca D, Ciccotelli R, et al. (2019) Early evaluation of five age-correlated DNA methylation markers in an Italian population sample. Forensic Sci. Int. Genet SupplSer 7: 424-426.

42. Xu Y, Li X, Yang Y, Li C, Shao X, et al. (2019) Human age prediction based on DNA methylation of non-blood tissues. Comput Methods Programs Biomed 171: 11-18.

43. Dias HC, Cordeiro C, Real FC, Cunha E, Manco L, et al.(2020) Age Estimation Based on DNA Methylation Using Blood Samples From Deceased Individuals. J Forensic Sci 65: 465-470.

44. Heidegger A, Xavier C, Niederstätter H, Puente M, Pośpiech E, et al (2020) Development and optimization of the VISAGE basic prototype tool for forensic age estimation. Forensic SciInt Genet 48: 102322.

45. Lee HY, Hong SR, Lee JE, Hwang IK, Kim NY, et al. (2020) Epigenetic age signatures in bones. Forensic SciInt Genet 46: 102261.

46. Li L, Song F, Lang M, Hou J, Wang Z, et al. (2020) Methylation-Based Age Prediction Using Pyrosequencing Platform from Seminal Stains in Han Chinese Males. J Forensic Sci 65: 610-619.

47. Pan C, Yi S, Xiao C, Huang Y, Chen X, et al. (2020) The evaluation of seven age-related $\mathrm{CpGs}$ for forensic purpose in blood from Chinese Han population. Forensic SciInt Genet 46: 102251.

48. ELOVL2, GeneCards ${ }^{\circledR}$ : The Human Gene Database.

49. Chen D, Chao DL, Rocha L, Kolar M, Huu VAN, et al. (2020) The lipid elongation enzyme ELOVL2 is a molecular regulator of aging in the retina. Aging Cell 19: 13100 .

50. Bacalini MG, Deelen J, Pirazzini C, Cecco MD, Giuliani C, et al. (2017) Systemic Age-Associated DNA Hypermethylation of ELOVL2 Gene: In Vivo and In Vitro Evidences of a Cell Replication Process. J GerontolA BiolSci Med Sci 72: 1015-1023.
51. De Magalhães JP, Faragher RGA. (2008) Cell divisions and mammalian aging: integrative biology insights from genes that regulate longevity. Bioessays 30: 567-578.

52. FHL2, GeneCards ${ }^{\circledR}$ : The Human Gene Database.

53. WixlerV(2019) The role of FHL2 in wound healing and inflammation. FASEB J 33: 7799-7809.

54. Cao CY, Mok SW, Cheng VW, Tsui SK (2015) The FHL2 regulation in the transcriptional circuitry of human cancers. Gene 572: 1-7.

55. KLF14, GeneCards ${ }^{\circledR}$ : The Human Gene Database.

56. Yang M, Ren Y, Lin Z, Tang C, Jia Y, et al. (2015) Krüppel-like factor 14 increases insulin sensitivity through activation of PI3K/Akt signal pathway. Cell Signal 27: 2201-2208.

57. Assuncao TM, Lomberk G, Cao S, Yaqoob U, Mathison A, et al. (2014) New Role for Kruppel-like Factor 14 as a Transcriptional Activator Involved in the Generation of Signaling Lipids. J BiolChem 289: 1579815809 .

58. Wei X, Yang R, Wang C, Jian X, Li L, et al. (2017) A novel role for the Krüppel-like factor 14 on macrophage inflammatory response and atherosclerosis development. Cardiovasc Pathol 27: 1-8.

59. Spólnicka M, Pośpiech E, Adamczyk JG, Freire-Aradas A, Pepłońska B, et al. (2018) Modified aging of elite athletes revealed by analysis of epigenetic age markers. Aging 10: 241-252.

60. TRIM59, GeneCards ${ }^{\circledR}$ : The Human Gene Database.

61. Valiyeva F, Jiang F, Elmaadawi A, Moussa M, Yee S-P, et al. (2011) Characterization of the oncogenic activity of the novel TRIM59 gene in mouse cancer models. Mol Cancer Ther 10: 1229-1240.

62. Hu SH, Zhao MJ, Wang WX, Xu CW, Wang GD, et al. (2017) TRIM59 is a key regulator of growth and migration inrenal cell carcinoma. Cell MolBiol 63: 68-74

63. C1orf1320, GeneCards ${ }^{\circledR}$ : The Human Gene Database.

64. Marcucci G, Mrózek K, Radmacher MD, Garzon R, Bloomfield CD, et al.(2011) The prognostic and functional role of microRNAs in acute myeloid leukemia. Blood 117: 1121-1129. 
Citation: Silva DSBS, Karantenislis G (2021) Analysis of DNA Methylation Sites used for Forensic Age Prediction and their Correlation with Human Aging. Forensic Leg InvestigSci 7: 054.

\begin{tabular}{|c|c|c|c|}
\hline Gene & $\begin{array}{l}\text { Number of studies using } \\
\text { the gene }\end{array}$ & Gene role & GeneCards/NCBI reference \\
\hline ELOVL2 & 16 & $\begin{array}{l}\text { metabolism, and transferase and fatty acid elongase activ- } \\
\text { ities }\end{array}$ & https://www.genecards.org/cgi-bin/carddisp.pl?gene=ELOVL2 \\
\hline FHL2 & 11 & assembly of extracellular membranes & $\begin{array}{l}\text { https://www.genecards.org/cgi-bin/carddisp.pl?gene=FHL2\&key- } \\
\text { words=FHL2 }\end{array}$ \\
\hline KLF14 & 10 & transcriptional repression & $\begin{array}{l}\text { https://www.genecards.org/cgi-bin/carddisp.p1?- } \\
\text { gene=KLF14\&keywords=KLF14 }\end{array}$ \\
\hline TRIM59 & 8 & regulator for innate immune signaling pathways & https://www.genecards.org/cgi-bin/carddisp.pl?gene=TRIM59 \\
\hline C1orf132/MIR29B2CHG & 7 & mir-29 microRNA precursor & $\begin{array}{l}\text { https://www.genecards.org/cgi-bin/carddisp.pl?gene=MIR29B- } \\
\text { 2CHG\&keywords=C1orf132 }\end{array}$ \\
\hline ASPA & 6 & maintain white matter & $\begin{array}{l}\text { https://www.genecards.org/cgi-bin } / \text { carddisp.p1? - } \\
\text { gene=ASPA\&keywords=ASPA }\end{array}$ \\
\hline PDE4C & 6 & regulation of cellular concentration of cAMP & $\begin{array}{l}\text { https://www.genecards.org/Search/Keyword?queryString=P- } \\
\text { DE4C }\end{array}$ \\
\hline CCDC102B & 4 & centrosome cohesion and centrosome linker assembly & https://www.ncbi.nlm.nih.gov/gene/79839 \\
\hline EDARADD & 4 & morphogenesis of ectodermal organs & https://www.genecards.org/cgi-bin/carddisp.pl?gene=EDARADD \\
\hline ITGA2B & 4 & blood coagulation system & https://www.genecards.org/cgi-bin/carddisp.pl?gene=ITGA2B \\
\hline SCGN & 4 & KCL-stimulated calcium flux and cell proliferation & https://www.genecards.org/cgi-bin/carddisp.pl?gene=SCGN \\
\hline CSNK1D & 3 & diverse cellular growth and survival processes & https://www.genecards.org/cgi-bin/carddisp.pl?gene=CSNK1D \\
\hline NHLRC1 & 3 & suppression of cellular toxicity by protein degradation & https://www.genecards.org/cgi-bin/carddisp.pl?gene=NHLRC1 \\
\hline NOX4 & 2 & $\begin{array}{l}\text { signal transduction, cell differentiation and tumor cell } \\
\text { growth }\end{array}$ & https://www.genecards.org/cgi-bin/carddisp.pl?gene=NOX4 \\
\hline NPTX2 & 2 & excitatory synapse formation & $\begin{array}{l}\text { https://www.genecards.org/cgi-bin/carddisp.pl?gene=NPTX- } \\
\text { 2\&keywords=NPTX2 }\end{array}$ \\
\hline ZNF423 & 2 & signal transduction during development & https://www.genecards.org/cgi-bin/carddisp.pl?gene=ZNF423 \\
\hline ADAR & 1 & RNA editing & https://www.genecards.org/cgi-bin/carddisp.pl?gene=ADAR \\
\hline B3GALT6 & 1 & transfer of galactose and glycosaminoglycan synthesis & https://www.genecards.org/cgi-bin/carddisp.pl?gene=B3GALT6 \\
\hline C16orf30 & 1 & $\begin{array}{l}\text { cell adhesion and cellular permeability at adherens junc- } \\
\text { tions }\end{array}$ & https://www.genecards.org/cgi-bin/carddisp.pl?gene=TMEM204 \\
\hline C17orf76/LRRC75A & 1 & protein-protein interactions & https://www.ncbi.nlm.nih.gov/gene/388341 \\
\hline C21 orf63/EVA1C & 1 & carbohydrate binding & $\begin{array}{l}\text { https://www.genecards.org/cgi-bin/carddisp.p1?- } \\
\text { gene=EVA1C\&keywords=C21orf63 }\end{array}$ \\
\hline CNGA3 & 1 & normal vision and olfactory signal transduction & https://www.genecards.org/cgi-bin/carddisp.pl?gene $=$ CNGA3 \\
\hline DMH & 1 & $\begin{array}{l}\text { integrator of intermediate filaments, actin and microtubule } \\
\text { cytoskeleton networks }\end{array}$ & $\begin{array}{l}\text { https://www.genecards.org/cgi-bin/carddisp.pl?gene=DST\&key- } \\
\text { words=DMH }\end{array}$ \\
\hline EPHA6 & 1 & transferase activity & https://www.genecards.org/cgi-bin/carddisp.pl?gene=EPHA6 \\
\hline ERG & 1 & $\begin{array}{l}\text { embryonic development, cell proliferation, differentiation, } \\
\text { angiogenesis, inflammation, and apoptosis }\end{array}$ & https://www.genecards.org/cgi-bin/carddisp.pl?gene=ERG \\
\hline F5 & 1 & blood coagulation cascade & https://www.genecards.org/cgi-bin/carddisp.pl?gene=F5 \\
\hline FLJ25410/SEPTIN12 & 1 & $\begin{array}{l}\text { cytokinesis, exocytosis, embryonic development, and } \\
\text { membrane dynamics }\end{array}$ & https://www.genecards.org/cgi-bin/carddisp.pl?gene=SEPTIN12 \\
\hline FXN & 1 & mitochondrial iron transport and respiration & https://www.genecards.org/cgi-bin/carddisp.pl?gene=FXN \\
\hline FZD9 & 1 & $\begin{array}{l}\text { neuromuscular junction assembly, neural progenitor cells } \\
\text { viability and neuroblast proliferation and apoptotic cell } \\
\text { death }\end{array}$ & https://www.genecards.org/cgi-bin/carddisp.pl?gene=FZD9 \\
\hline GPR137 & 1 & $\begin{array}{l}\text { MTORC1 complex translocation to lysosomes, autophagy } \\
\text { and epithelial cell function }\end{array}$ & https://www.genecards.org/cgi-bin/carddisp.pl?gene=GPR137 \\
\hline LAG3 & 1 & $\begin{array}{l}\text { innate Immune System and Class I MHC mediated antigen } \\
\text { processing and presentation }\end{array}$ & https://www.genecards.org/cgi-bin/carddisp.pl?gene=LAG3 \\
\hline LEP & 1 & $\begin{array}{l}\text { regulation of energy homeostasis, immune and inflamma- } \\
\text { tory responses, hematopoiesis, angiogenesis, reproduction, } \\
\text { bone formation and wound healing }\end{array}$ & https://www.genecards.org/cgi-bin/carddisp.pl?gene=LEP \\
\hline MBP & 1 & $\begin{array}{l}\text { protease binding and structural constituent of myelin } \\
\text { sheath }\end{array}$ & https://www.genecards.org/cgi-bin/carddisp.pl?gene=MBP \\
\hline
\end{tabular}


Citation: Silva DSBS, Karantenislis G (2021) Analysis of DNA Methylation Sites used for Forensic Age Prediction and their Correlation with Human Aging. Forensic Leg InvestigSci 7: 054.

\begin{tabular}{|c|c|c|c|}
\hline MEIS1 & 1 & $\begin{array}{l}\text { hematopoiesis, megakaryocyte lineage development and } \\
\text { vascular patterning }\end{array}$ & https://www.genecards.org/cgi-bin/carddisp.pl?gene=MEIS1 \\
\hline $\mathrm{NOC} 2 \mathrm{~L}$ & 1 & inhibition of histone acetyltransferase activity & https://www.genecards.org/cgi-bin/carddisp.pl?gene=NOC2L \\
\hline P2RXL1 & 1 & identical protein binding and ion channel activity & https://www.genecards.org/cgi-bin/carddisp.pl?gene=P2RX6 \\
\hline PENK & 1 & $\begin{array}{l}\text { physiologic functions, including pain perception and re- } \\
\text { sponses to stress }\end{array}$ & https://www.genecards.org/cgi-bin/carddisp.pl?gene=PENK \\
\hline PTDSS2 & 1 & metabolism and glycerophospholipid biosynthesis & https://www.genecards.org/cgi-bin/carddisp.pl?gene=PTDSS2 \\
\hline PTPN7 & 1 & $\begin{array}{l}\text { cell growth, differentiation, mitotic cycle, and oncogenic } \\
\text { transformation }\end{array}$ & https://www.genecards.org/cgi-bin/carddisp.pl?gene=PTPN7 \\
\hline RASSF5 & 1 & tumor suppressor & https://www.genecards.org/cgi-bin/carddisp.pl?gene=RASSF5 \\
\hline SALL4 & 1 & $\begin{array}{l}\text { development of abducens motor neurons and maintenance } \\
\text { and self-renewal of embryonic and hematopoietic stem } \\
\text { cells }\end{array}$ & https://www.genecards.org/cgi-bin/carddisp.pl?gene=SALL4 \\
\hline SCAP & 1 & cholesterol and lipid homeostasis & https://www.genecards.org/cgi-bin/carddisp.pl?gene=SCAP \\
\hline SLC12A5 & 1 & $\begin{array}{l}\text { protein kinase binding and potassium:chloride symporter } \\
\text { activity }\end{array}$ & https://www.genecards.org/cgi-bin/carddisp.pl?gene=SLC12A5 \\
\hline SLC22A18 & 1 & tumor suppressor & https://www.genecards.org/cgi-bin/carddisp.pl?gene=SLC22A18 \\
\hline SNN & 1 & toxic effects of organotins and endosomal maturation & https://www.genecards.org/cgi-bin/carddisp.pl?gene=SNN \\
\hline SSRP1 & 1 & chromatin transcriptional elongation factor FACT & https://www.genecards.org/cgi-bin/carddisp.pl?gene=SSRP1 \\
\hline SST & 1 & hormone activity & https://www.genecards.org/cgi-bin/carddisp.pl?gene=SST \\
\hline ТВOX3 & 1 & $\begin{array}{l}\text { developmental processes, limb pattern formation and regu- } \\
\text { lation of PML function in cellular senescence }\end{array}$ & $\begin{array}{l}\text { https://www.genecards.org/cgi-bin/carddisp.pl?gene=TBX- } \\
\text { 3\&keywords=T-BOX3 }\end{array}$ \\
\hline TBR1 & 1 & $\begin{array}{l}\text { cortical development, including neuronal migration, lami- } \\
\text { nar and areal identity, and axonal projection }\end{array}$ & https://www.genecards.org/cgi-bin/carddisp.pl?gene=TBR1 \\
\hline TMEM106A & 1 & Activation and polarization of macrophages & $\begin{array}{l}\text { https://www.genecards.org/cgi-bin/carddisp.pl?gene=TME- } \\
\text { M106A }\end{array}$ \\
\hline TMEM51/C1orf72 & 1 & unkown & $\begin{array}{l}\text { https://www.genecards.org/cgi-bin/carddisp.p1?gene }=\mathrm{T}- \\
\text { MEM51\&keywords=TMEM51 }\end{array}$ \\
\hline TRIP10 & 1 & identical protein binding and lipid binding & https://www.genecards.org/cgi-bin/carddisp.pl?gene=TRIP10 \\
\hline TSSK6 & 1 & $\begin{array}{l}\text { sperm production and function, and DNA condensation } \\
\text { during postmeiotic chromatin remodeling }\end{array}$ & https://www.genecards.org/cgi-bin/carddisp.pl?gene=TSSK6 \\
\hline \multicolumn{4}{|l|}{ TTC7B } \\
\hline & 1 & $\begin{array}{l}\text { regulation of phosphatidylinositol 4-phosphate (PtdIns(4) } \\
\text { P) synthesis }\end{array}$ & $\begin{array}{l}\text { https://www.genecards.org/cgi-bin/carddisp.pl?gene=TTC- } \\
\text { 7B\&keywords=TTC7B }\end{array}$ \\
\hline UBE2E1 & 1 & $\begin{array}{l}\text { photodynamic therapy-induced unfolded protein response } \\
\text { and regulation of activated PAK-2p34 by proteasome me- } \\
\text { diated degradation }\end{array}$ & https://www.genecards.org/cgi-bin/carddisp.pl?gene=UBE2E1 \\
\hline UBQLN1 & 1 & protein degradation mechanisms and pathways & https://www.genecards.org/cgi-bin/carddisp.pl?gene=UBQLN1 \\
\hline VGF & 1 & growth factor activity and neuropeptide hormone activity & https://www.genecards.org/cgi-bin/carddisp.pl?gene=VGF \\
\hline ZDHHC22 & 1 & protein-cysteine S-palmitoyltransferase activity & https://www.genecards.org/cgi-bin/carddisp.pl?gene=ZDHHC22 \\
\hline ZIC4 & 1 & $\begin{array}{l}\text { development and X-linked visceral heterotaxy and holo- } \\
\text { prosencephaly type } 5\end{array}$ & https://www.genecards.org/cgi-bin/carddisp.pl?gene=ZIC4 \\
\hline
\end{tabular}

Supplementary Table 1: Identified genes and their functions. All genes are protein coding genes, except for C1orf132 (ncRNA gene type). 


\section{Hif}

Advances In Industrial Biotechnology | ISSN: 2639-5665

Advances In Microbiology Research | ISSN: 2689-694X

Archives Of Surgery And Surgical Education | ISSN: 2689-3126

Archives Of Urology

Archives Of Zoological Studies | ISSN: 2640-7779

Current Trends Medical And Biological Engineering

International Journal Of Case Reports And Therapeutic Studies | ISSN: 2689-310X

Journal Of Addiction \& Addictive Disorders | ISSN: 2578-7276

Journal Of Agronomy \& Agricultural Science | ISSN: 2689-8292

Journal Of AIDS Clinical Research \& STDs | ISSN: 2572-7370

Journal Of Alcoholism Drug Abuse \& Substance Dependence | ISSN: 2572-9594

Journal Of Allergy Disorders \& Therapy | ISSN: 2470-749X

Journal Of Alternative Complementary \& Integrative Medicine | ISSN: 2470-7562

Journal Of Alzheimers \& Neurodegenerative Diseases | ISSN: 2572-9608

Journal Of Anesthesia \& Clinical Care | ISSN: 2378-8879

Journal Of Angiology \& Vascular Surgery | ISSN: 2572-7397

Journal Of Animal Research \& Veterinary Science | ISSN: 2639-375

Journal Of Aquaculture \& Fisheries | ISSN: 2576-5523

Journal Of Atmospheric \& Earth Sciences | ISSN: 2689-8780

Journal Of Biotech Research \& Biochemistry

Journal Of Brain \& Neuroscience Research

Journal Of Cancer Biology \& Treatment | ISSN: 2470-7546

Journal Of Cardiology Study \& Research | ISSN: 2640-768X

Journal Of Cell Biology \& Cell Metabolism | ISSN: 2381-1943

Journal Of Clinical Dermatology \& Therapy | ISSN: 2378-8771

Journal Of Clinical Immunology \& Immunotherapy | ISSN: 2378-8844

Journal Of Clinical Studies \& Medical Case Reports | ISSN: 2378-880

Journal Of Community Medicine \& Public Health Care | ISSN: 2381-1978

Journal Of Cytology \& Tissue Biology | ISSN: 2378-9107

Journal Of Dairy Research \& Technology | ISSN: 2688-9315

Journal Of Dentistry Oral Health \& Cosmesis | ISSN: 2473-6783

Journal Of Diabetes \& Metabolic Disorders | ISSN: 2381-201X

Journal Of Emergency Medicine Trauma \& Surgical Care | ISSN: 2378-8798

Journal Of Environmental Science Current Research | ISSN: 2643-5020

Journal Of Food Science \& Nutrition | ISSN: 2470-1076

Journal Of Forensic Legal \& Investigative Sciences | ISSN: 2473-733X

Journal Of Gastroenterology \& Hepatology Research | ISSN: 2574-2566
Journal Of Genetics \& Genomic Sciences | ISSN: 2574-2485

Journal Of Gerontology \& Geriatric Medicine | ISSN: 2381-8662

Journal Of Hematology Blood Transfusion \& Disorders | ISSN: 2572-2999

Journal Of Hospice \& Palliative Medical Care

Journal Of Human Endocrinology | ISSN: 2572-9640

Journal Of Infectious \& Non Infectious Diseases | ISSN: 2381-8654

Journal Of Internal Medicine \& Primary Healthcare | ISSN: 2574-2493

Journal Of Light \& Laser Current Trends

Journal Of Medicine Study \& Research | ISSN: 2639-5657

Journal Of Modern Chemical Sciences

Journal Of Nanotechnology Nanomedicine \& Nanobiotechnology | ISSN: 2381-2044

Journal Of Neonatology \& Clinical Pediatrics | ISSN: 2378-878X

Journal Of Nephrology \& Renal Therapy | ISSN: 2473-7313

Journal Of Non Invasive Vascular Investigation | ISSN: 2572-7400

Journal Of Nuclear Medicine Radiology \& Radiation Therapy | ISSN: 2572-7419

Journal Of Obesity \& Weight Loss | ISSN: 2473-7372

Journal Of Ophthalmology \& Clinical Research | ISSN: 2378-8887

Journal Of Orthopedic Research \& Physiotherapy | ISSN: 2381-2052

Journal Of Otolaryngology Head \& Neck Surgery | ISSN: 2573-010X

Journal Of Pathology Clinical \& Medical Research

Journal Of Pharmacology Pharmaceutics \& Pharmacovigilance | ISSN: 2639-5649

Journal Of Physical Medicine Rehabilitation \& Disabilities | ISSN: 2381-8670

Journal Of Plant Science Current Research | ISSN: 2639-3743

Journal Of Practical \& Professional Nursing | ISSN: 2639-568

Journal Of Protein Research \& Bioinformatics

Journal Of Psychiatry Depression \& Anxiety | ISSN: 2573-0150

Journal Of Pulmonary Medicine \& Respiratory Research | ISSN: 2573-0177

Journal Of Reproductive Medicine Gynaecology \& Obstetrics | ISSN: 2574-2574

Journal Of Stem Cells Research Development \& Therapy | ISSN: 2381-2060

Journal Of Surgery Current Trends \& Innovations | ISSN: 2578-7284

Journal Of Toxicology Current Research | ISSN: 2639-3735

Journal Of Translational Science And Research

Journal Of Vaccines Research \& Vaccination | ISSN: 2573-0193

Journal Of Virology \& Antivirals

Sports Medicine And Injury Care Journal | ISSN: 2689-8829

Trends In Anatomy \& Physiology | ISSN: 2640-7752

Submit Your Manuscript: https://www.heraldopenaccess.us/submit-manuscript 